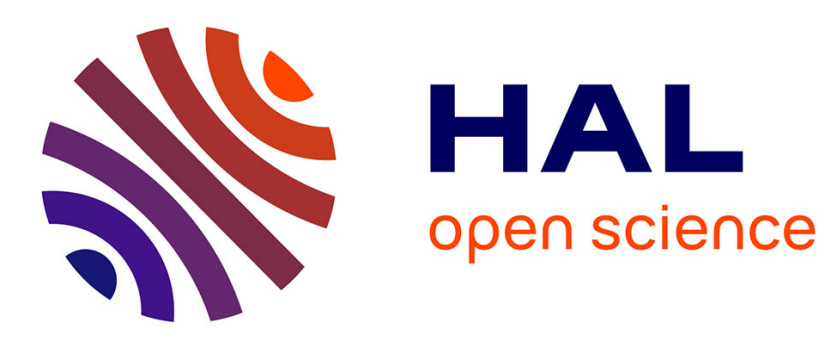

\title{
In-depth characterization of bacterial and archaeal communities present in the abandoned Kettara pyrrhotite mine tailings (Morocco)
}

Odile Bruneel, N. Mghazli, R. Hakkou, I. Dahmani, A. Filali Maltouf, L. Sbabou

\section{To cite this version:}

Odile Bruneel, N. Mghazli, R. Hakkou, I. Dahmani, A. Filali Maltouf, et al.. In-depth characterization of bacterial and archaeal communities present in the abandoned Kettara pyrrhotite mine tailings (Morocco). Extremophiles, 2017, 21 (4), pp.671-685. 10.1007/s00792-017-0933-3 . hal-03143128

\section{HAL Id: hal-03143128 \\ https://hal.umontpellier.fr/hal-03143128}

Submitted on 8 Feb 2022

HAL is a multi-disciplinary open access archive for the deposit and dissemination of scientific research documents, whether they are published or not. The documents may come from teaching and research institutions in France or abroad, or from public or private research centers.
L'archive ouverte pluridisciplinaire HAL, est destinée au dépôt et à la diffusion de documents scientifiques de niveau recherche, publiés ou non, émanant des établissements d'enseignement et de recherche français ou étrangers, des laboratoires publics ou privés. 


\title{
In-depth characterization of bacterial and archaeal communities present in the abandoned Kettara pyrrhotite mine tailings (Morocco)
}

\author{
Odile Bruneel $^{1,2} \cdot$ N. Mghazli $^{1}$ - R. Hakkou ${ }^{3}$ I. Dahmani ${ }^{1} \cdot$ A. Filali Maltouf ${ }^{1} \cdot$ \\ L. Sbabou ${ }^{1}$
}

\begin{abstract}
In Morocco, pollution caused by closed mines continues to be a serious threat to the environment, like the generation of acid mine drainage. Mine drainage is produced by environmental and microbial oxidation of sulfur minerals originating from mine wastes. The fundamental role of microbial communities is well known, like implication of Fe-oxidizing and to a lesser extent S-oxidizing microorganism in bioleaching. However, the structure of the microbial communities varies a lot from one site to another, like diversity depends on many factors such as mineralogy, concentration of metals and metalloids or $\mathrm{pH}$, etc. In this study, prokaryotic communities in the pyrrhotite-rich tailings of Kettara mine were characterized using the Illumina sequencing. In-depth phylogenetic analysis revealed a total of 12 phyla of bacteria and 1 phyla of Archaea. The majority of sequences belonged to the phylum of Proteobacteria and Firmicutes with a predominance
\end{abstract}

Odile Bruneel

odile.bruneel@ird.fr

1 Laboratoire de Microbiologie et Biologie Moléculaire, LMBM, Faculté des Sciences, Université Mohammed V, Av Ibn Batouta, BP1014, Rabat, Morocco

2 Laboratoire HydroSciences Montpellier, UMR5569 (CNRS/ IRD/UM), Université de Montpellier, CC0057 (MSE), 16, rue Auguste Broussonet, 34090 Montpellier, France

3 Laboratoire de Chimie des Matériaux et de l'Environnement (LCME), Faculté des Sciences et Technique Guéliz, Université de Cadi Ayyad, Avenue Abdelkarim Elkhattabi, Gueliz, P.O. Box 549, Marrakech, Morocco of Bacillus, Pseudomonas or Corynebacterium genera. Many microbial populations are implicated in the iron, sulfur and arsenic cycles, like Acidiferrobacter, Leptospirillum, or Alicyclobacillus in Fe; Acidiferrobacter and Sulfobacillus in S; and Bacillus or Pseudomonas in As. This is one of the first description of prokaryotic communities in pyrrhotite-rich mine tailings using high-throughput sequencing.

Keywords Microbial diversity · Pyrrhotite-rich tailings · Intermittent acid mine drainage $\cdot$ Illumina sequencing . Kettara mine

\section{Introduction}

The mining of metallic sulfide ores produces huge quantities of sulfide-rich mine wastes that generate acid mine drainage (AMD) when exposed to oxygen and water (Hallberg 2010). Although this process occurs naturally, mining operations like excavation and milling accelerate the process by increasing the exposure of sulfide minerals to water, oxygen and microorganisms (Simate and Ndlovu 2014). AMD generally contains high concentrations of sulfates, iron, metals $(\mathrm{Pb}, \mathrm{Cd}, \mathrm{Zn})$, and metalloids like arsenic, with acid $\mathrm{pH}$, that represent a threat to the environment and to human health with high environmental and socio-economic costs (Akcil and Koldas 2006; Hallberg 2010).

The overall reaction of the oxidation of pyrite $\left(\mathrm{FeS}_{2}\right.$, the most abundant sulfide mineral on Earth) can be written as: $\mathrm{FeS}_{2}+14 \mathrm{Fe}^{3+}+8 \mathrm{H}_{2} \mathrm{O} \rightarrow 15 \mathrm{Fe}^{2+}+2 \mathrm{SO}_{4}{ }^{2-}+16 \mathrm{H}^{+} . \mathrm{In}$ contrast to $\mathrm{FeS}_{2}$ oxidation, acid-soluble metal sulfides like pyrrhotite $\left(\mathrm{Fe}_{1-x} \mathrm{~S}\right.$ with $\left.x=0-0.125\right)$ can be dissolved by the combined action of $\mathrm{Fe}(\mathrm{III})$ oxidative attacks (the most widespread oxidant in acidic environments) and proton 
attacks (Vera et al. 2013). The main role of microorganisms in leaching consists in the regeneration of $\mathrm{Fe}$ (III) ions (Schippers and Sand 1999), by microorganisms such as Acidithiobacillus ferrooxidans capable of increasing the iron oxidation rate one hundred to one million fold (Singer and Stumm 1970). Elemental sulfur can be also biologically oxidized to sulfuric acid thus contributing to the dissolution of pyrrhotite. Furthermore, S-oxidizing microorganisms can minimize the accumulation of elemental sulfur on the surface of the metal sulfide, which is known to reduce metal sulfide dissolution (reviewed in Vera et al. 2013).

Microbial populations in mine tailings have attracted considerable interest in the last decade. Indeed, knowledge of bioleaching microorganisms can be of great importance for the long-term prediction of mine waste and the development and monitoring of countermeasures to limit the pollution (Rawlings and Johnson 2007; Schippers et al. 2010; Chen et al. 2013). The microorganisms involved in sulfidic mine waste generating AMD are similar to those used in commercial leaching operations to recover precious and base metals, so understanding how they function could have a strong economic impact (Schippers et al. 2010). Concerning the bioleaching of metal sulfides, the best studied bacterial strains are Acidithiobacillus ferrooxidans (the first isolated) or Leptospirillum ferrooxidans. However, in recent decades research has revealed a much wider diversity of leaching bacteria than previously thought, with bacteria distributed among different phyla like Proteobacteria (including Acidithiobacillus, Acidiferrobacter, Ferrovum); Nitrospirae (Leptospirillum); Firmicutes (Alicyclobacillus, Sulfobacillus) or Actinobacteria (Acidimicrobium, Ferrimicrobium or Ferrithrix, Vera et al. 2013). Many iron- and sulfur-oxidizing Archaea strains have also been found in the order of Sulfolobales, such as Sulfolobus, Acidianus, Metallosphaera, Sulfurisphaera, etc., or in the Thermoplasmales like Ferroplasma (Schippers et al. 2010; Vera et al. 2013).

Although the chemistry of AMD generation is well known, their characteristics vary greatly from one region to another and the production of AMD is a function of the geology of the mining site, the type of microorganisms present, the concentration of metals and metalloids, the temperature, the $\mathrm{pH}$, and the presence of water and oxygen (Schippers et al. 2007; Chen et al. 2013; Simate and Ndlovu 2014). In the last decade, rapid advances in sequencing technology have revolutionized microbial ecology, from sequencing hundreds of $16 \mathrm{~S}$ rRNA gene fragments per study with clone libraries to millions of fragments using next-generation sequencing (NGS) technologies like 454 or Illumina. This has greatly improved our understanding of the composition and diversity of microbial communities in the environment (Caporaso et al. 2011; Kozich et al. 2013).
The abandoned Kettara mine is a problematic mine site located near the city of Marrakech (Morocco), where inhabitants are directly exposed (Lghoul et al. 2014). The sulfide deposit is composed of major and minor lenses of massive pyrrhotite, with small amounts of sphalerite, galena, chalcopyrite, pyrite, arsenopyrite and glaucodot (Khalil et al. 2013). The substrate is composed of fractured and altered shale, which facilitates AMD infiltration into the groundwater. The groundwater table is located at a depth of only 10-20 m, and is contaminated by AMD with high concentration of sulfates and high conductivity (Lghoul et al. 2012; Khalil et al. 2013).

The aim of the present work was to characterize the diversity and taxonomic composition of the microbial communities (archaea and bacteria) using a MiSeq approach targeting the 16S rRNA gene and to investigate their spatial evolution in relation to the physicochemical structure of the tailings. Our results provide insights into the potential role of microorganisms in the formation of AMD at the abandoned Kettara pyrrhotite ore mine, which is located in a semi-arid environment.

\section{Experimental procedures}

\section{Study area}

Kettara pyrrhotite mine is located $30 \mathrm{~km}$ north-west of Marrakech (Morocco) and was exploited for the production of sulfuric acid from 1965 to 1982 (Hakkou et al. 2008a). The mine produced more than 5.2 million metric tons of pyrrhotite concentrate containing an average of $1.6-14.5 \mathrm{wt} \%$ sulfur, mainly as sulfide minerals (e.g., pyrrhotite, pyrite, chalcopyrite, galena, and sphalerite, Hakkou et al. 2008a; Khalil et al. 2013). Three million tons of mine residues were directly stored on a shale and sandstone fractured bedrock distributed over an area of approximately 16 ha, without any concern for the environment (Khalil et al. 2013). The tailings materials can be divided into two broad classes: coarse tailings (fine gravel) deposited on the 15-m-high dyke or on 1-m-high piles, and fine mine residues (silt) stored in the tailings pond (Hakkou et al. 2008a). The climate is semi-arid with mean annual rainfall of approximately $250 \mathrm{~mm}$, characterized by short but intensive rainfall events (Lghoul et al. 2014). Sulfide minerals can be easily oxidized due to the high hydraulic permeability of the tailings, generating AMD after each rainfall event characterize by acid $\mathrm{pH}$ (ranging from 2.4 to 3.4 ) and very high concentrations of sulfate (8000-49600 $\mathrm{mg} \mathrm{l}^{-1}$ ), Fe (40-1650 $\mathrm{mg}^{-1}$ ), and Al (730-4170 $\mathrm{mg} \mathrm{l}^{-1}$, Lghoul et al. 2014). Results of laboratory experiments confirmed field observations indicating that fine and coarse tailings at Kettara are highly acid generating (Hakkou et al. 2008a, b). 
The mining village of Kettara (with around 2000 inhabitants) is located downstream from the tailings pond. Groundwater, sampled from wells in Kettara village, is contaminated by AMD (Lghoul et al. 2012; Toughzaoui et al. 2015). Furthermore, windblown dust and sulfur emanations represent a real threat for the village inhabitants and farms in the vicinity (Babi et al. 2015).

\section{Sample collection}

Nine tailings samples were collected from the field site in September 2014, after a dry and hot summer, and were analyzed in the laboratory to determine their chemical composition. Sampling locations are shown in Fig. 1 and Table S1.

Three trenches were excavated to a depth of 60 and $120 \mathrm{~cm}$ in the tailings pond. In each trench, significant variations in color were observed, unoxidized tailings being grey and oxidized tailings yellowish-brown (Table S1). In trench 1, samples of fresh, unaltered fine tailings (T1-RF) were taken at a depth of $60-70 \mathrm{~cm}$ and samples of oxidized fine tailings (T1-RO) at a depth of $4-5 \mathrm{~cm}$. In trench 2, unaltered fine tailings (T2-RF) were sampled at a depth of $40-50 \mathrm{~cm}$, and samples of oxidized fine tailings (T2-RO) at a depth of $4-5 \mathrm{~cm}$. Trench 3 was excavated in the main dyke, corresponding to the coarse tailings whose oxidized zone was thicker than those observed in the fine tailings. Samples of unaltered coarse tailings (T3-S1F) were taken at a depth of 110-120 cm and samples of oxidized coarse tailings (T3-S1O) at a depth of 4-5 cm. Secondary precipitates (called D8) were sampled in the dyke and correspond to clear grey efflorescent salts. Samples K1 and K2 were taken at a depth of 4-5 cm in the 1-m-high piles of coarse tailings. Samples for chemical analysis were preserved at $4{ }^{\circ} \mathrm{C}$ until processing, and samples for DNA extraction were preserved on the field at $4{ }^{\circ} \mathrm{C}$ then stored at $-80{ }^{\circ} \mathrm{C}$ until analysis.

\section{Characterization of tailing samples}

The chemical composition of the tailings was determined with a thermo scientific NITON X-ray fluorescence (XRF) analyzer (Thermo Scientific NITON 2008). The quality of the data was assessed using duplicate sample analyses and measurement accuracy was estimated at $\pm 5 \%$ for all the elements analyzed. $\mathrm{pH}$ was analyzed according to the method of Mathieu and Pieltain (2003).
Fig. 1 Map of the Kettara mining site and location of the 9 sampling stations, sampled in September 2014. 1 T1-RF, 2 T1-RO, 3 T2-RF, 4 T2-RO, 5 T3-S1F, 6 T3-S1O, 7 D8, 8 K1 and $9 \mathrm{~K} 2$

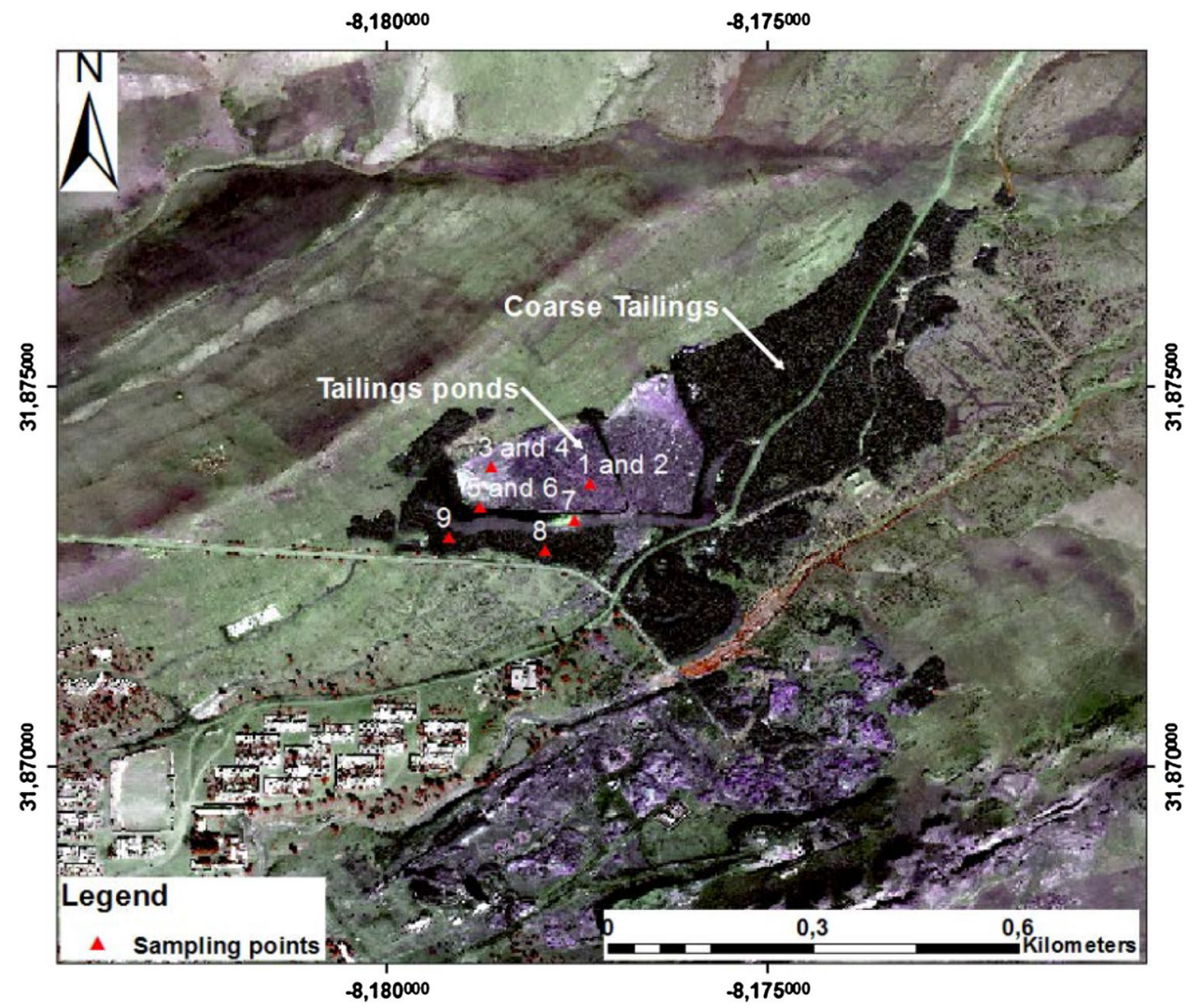




\section{DNA extraction, PCR amplification and Illumina MiSeq sequencing}

Genomic DNA was extracted in triplicate from sediments using the PowerSoil DNA Isolation Kit and analyzed following the manufacturer's recommendations (MoBio Laboratories Inc., Carlsbad, CA, USA). All extracted genomic DNA samples were stored at $-20{ }^{\circ} \mathrm{C}$ until further analysis.

The genes coding for 16S rRNA were amplified by PCR for multiplexed Illumina using barcoded primers. The universal primer set 515F (5'-GTGCCAGCMGCCGCGGTAA-3') and 806R (5'-GGACTACVSGGGTATCTAAT-3') designed to target nearly all bacterial and archaeal taxa (Bates et al. 2011) was used to amplify a 291-bp region targeting the V4 region of $16 \mathrm{~S}$ rRNA genes.

A PCR reaction was performed on all three extracted DNA samples using a different barcode for each sample. The reaction mixture was used in a 28-cycle PCR using the HotStarTaq Plus Master Mix Kit (Qiagen, USA) with the following program: $3 \mathrm{~min}$ at $94{ }^{\circ} \mathrm{C}$, followed by 28 cycles at $94{ }^{\circ} \mathrm{C}$ for $30 \mathrm{~s}, 53{ }^{\circ} \mathrm{C}$ for $40 \mathrm{~s}$ and $72{ }^{\circ} \mathrm{C}$ for $1 \mathrm{~min}$, and a final elongation step at $72{ }^{\circ} \mathrm{C}$ for $5 \mathrm{~min}$. After amplification, the PCR products were checked in $2 \%$ agarose gel to determine the success of amplification and the relative intensity of the bands. Samples were pooled and purified using calibrated Ampure XP beads. Then the pooled and purified PCR product was used to prepare a DNA library following the Illumina TruSeq DNA library preparation protocol. Sequencing was performed at MR DNA (http://www. mrdnalab.com, Shallowater, TX, USA) on an Illumina MiSeq 2x300 bp, following the manufacturer's guidelines.

\section{Processing and taxonomic classification}

Sequence data were processed (paired end reads were merged and fasta and qual files produced) using MR DNA analysis pipeline (MR DNA, Shallowater, TX, USA). Bioinformatics analyses were then processed using the mothur platform, version 1.35.1 (Schloss et al. 2009). The raw reads obtained from sequencing were quality trimmed (with a minimum Phred average quality score of 35 over a 50-bp window), with exact barcode and primer matching. Reads containing ambiguous characters and less than 150 nucleotides were removed. Identical sequences were grouped, and representative sequences were aligned against the SILVA bacterial and archaeal reference database using the Needleman-Wunsch algorithm (Needleman and Wunsch 1970). Only sequences aligned in the same area were kept. The resulting sequences were denoised using a pre-clustering method that allowed one mismatch (Huse et al. 2010; Schloss et al. 2011). Chimeric sequences were detected and removed using chimera uchime (Edgar et al. 2011) and sequences that did not classify to the level of kingdom or that classified as Eukaryota, chloroplasts, or mitochondria were deleted. The remaining high-quality sequences were used to generate a distance matrix and were clustered into operational taxonomic units (OTUs) defined with a cutoff of $97 \%$ using the average neighbor algorithm. Singletons were culled. The OTUs were phylogenetically classified to genus level using the naive Bayesian classifier (80\% confidence threshold) against a manually curated database derived from the RDP reference file (http://rdp.cme.msu. edu) and implemented in mothur. To obtain comparable data and to equalize the depth of sequencing, samples were downsized to 17557 reads by random re-sampling in triplicate (i.e., 52671 per site).

\section{Estimation of diversity and statistical analysis}

\section{Diversity indices}

Nonparametric Chao1 and Shannon alpha diversity estimates as well as the coverage and rarefaction curves for each sampling site were calculated using mothur software at $97 \%$ sequence similarity.

\section{Principal component analyses}

Statistical analyses were performed with R 3.3.1 (2016-0621) (R Development Core Team 2012) using the ade 4 and Vegan packages. Principal component analysis (PCA) was used to explore variations in the chemical composition of our set of environmental variables.

Non Metric Multidimensional Scaling (NMDS) was then used to graphically depict differences between microbial communities. The significance of the observed clustering of samples on the ordination plot was assessed by an Analysis OF SIMilarity (ANOSIM, 999 permutations). Environmental variables were fitted to the NMDS ordinations as vectors with the 'envfit' function of the 'vegan' package.

\section{Results}

\section{Physicochemical characteristics of the tailing samples}

The main physicochemical characteristics of the tailings samples collected from the different stations are listed in Table S2. The Kettara mine tailings were characterized by low $\mathrm{pH}$ (from 1.83 to 4.81 ) and by extremely high concentrations of $\mathrm{Fe}$ (up to $403561 \mathrm{mg} \mathrm{kg}^{-1}$ ), sulfur (up to $109013 \mathrm{mg} \mathrm{kg}^{-1}$ ), $\mathrm{Cu}$ (up to $2794 \mathrm{mg} \mathrm{kg}^{-1}$ ), As (up to $344 \mathrm{mg} \mathrm{kg}^{-1}$ ), or $\mathrm{Cr}$ (up to $436 \mathrm{mg} \mathrm{kg}^{-1}$ ). These values are higher than many of the geochemical background values established for Kettara mine by Khalil 
et al. (2013) $\left(\mathrm{Cu} \approx 43.8 \mathrm{mg} \mathrm{kg}^{-1}, \mathrm{~Pb} \approx 21.8 \mathrm{mg} \mathrm{kg}^{-1}\right.$, $\mathrm{Zn} \approx 102.6 \mathrm{mg} \mathrm{kg}^{-1}$, As $\approx 13.9 \mathrm{mg} \mathrm{kg}^{-1}$ and $\mathrm{Fe} \approx 56.978 \mathrm{mg} \mathrm{kg}^{-1}$ ).

Table $\mathrm{S} 2$ shows that in the trenches, the $\mathrm{pH}$ was always lower at the surface than at depth which, logically, would be linked with oxidation of pyrrhotite in the surface tailings impoundment that is more subject to weathering than deeper layers. The concentrations of $\mathrm{Fe}$ and $\mathrm{S}$ varied with depth and the values of samples taken in the oxidized zone near the surface were always slightly higher than those of the samples from the deeper unoxidized zone. The highest concentration of $\mathrm{Fe}, \mathrm{S}$, and $\mathrm{Cr}$ were measured in the oxidized zone of trench T1. Sampling site D8 contained the highest concentration of $\mathrm{Si}$, As and high concentrations of $\mathrm{S}$, but also the lowest concentrations of $\mathrm{Fe}, \mathrm{Zn}, \mathrm{Cu} \mathrm{Cr}, \mathrm{Mn}$, $\mathrm{Al}$ and $\mathrm{Mg}$ associated with the lowest $\mathrm{pH}$ (1.83) compared to the other sampling sites. The chemical composition of the coarse tailings in the dyke (T3-S1F and T3-S1O) and the piles $(\mathrm{K} 1-\mathrm{K} 2)$ was quite similar.

Principal component analysis, describing the variations of the chemical parameters of the 9 tailings mine samplings, have identified around four groups: the secondary precipitates (D8), the 2 oxidized (T1-RO and T2-RO, in surface) and unoxidized (T1-RF and T2-RF, in depth) parts of the fine tailings and the coarse tailings (T3-S1O, T3S1F, $\mathrm{K} 1$ and K2, Fig. 2). The first PCA axis, explaining around $53 \%$ of the variations, separated the tailing sample D8 and the oxidized (T1-RO and T2-RO) and unoxidized (T1-RF and T2-RF) parts of the fine tailings. The second PCA axis, explaining around $25 \%$ of the variations, separated the tailing sample D8 and the oxidized and unoxidized parts of the fine tailings. The chemical composition of the oxidized parts of the fine tailings (T1-RO and T2-RO) seems positively correlated with $\mathrm{S}$, and the chemical composition of the unoxidized parts of the fine tailings (T1-RF and T2-RF) seems positively correlated with $\mathrm{Zn}, \mathrm{Cu}, \mathrm{Mn}, \mathrm{Mg}$ and $\mathrm{pH}$. The chemical composition of the sample D8 seems positively correlated with $\mathrm{As}$ and $\mathrm{Si}$ and negatively correlated with $\mathrm{Fe}$ and $\mathrm{Cr}$. T1-RF and T2-RF contained the most important concentration of $\mathrm{Al}\left(60130\right.$ and $75557 \mathrm{mg} \mathrm{kg}^{-1}$, respectively) compared to $\mathrm{T} 1-\mathrm{RO}, \mathrm{T} 2-\mathrm{RO}$ and $\mathrm{D} 8$ (around $10000 \mathrm{mg} \mathrm{kg}^{-1}$ ).

\section{Sequencing results and diversity indices}

A total of 1584954 good-quality reads with a mean length of 272 bp were obtained from the nine samples through MiSeq sequencing analysis. The number of sequences per sample was then made equal by random resampling (17557 sequences in triplicate, i.e., 52671 sequences per site) giving 474039 good-quality reads (Table 1). The clustering of these sequences allowed the identification of 430 OTUs defined with $97 \%$ identity.

The rarefaction curves in Figure $\mathrm{S} 1$ tend to reach an asymptote for all of the samples, except for T3-S1O, suggesting that the majority of the microbial phylotypes present in each sample were identified. This was confirmed by the very high Good's coverage (100\%) for all samples (Table 1), which provides an estimate of sampling completeness. However, the total number of OTUs for each sample estimated by the Chaol estimator, indicated that the richness of the microbial communities was a little higher
Fig. 2 Principal component analysis (PCA) analysis of the Kettara mine tailings and associated environmental variables

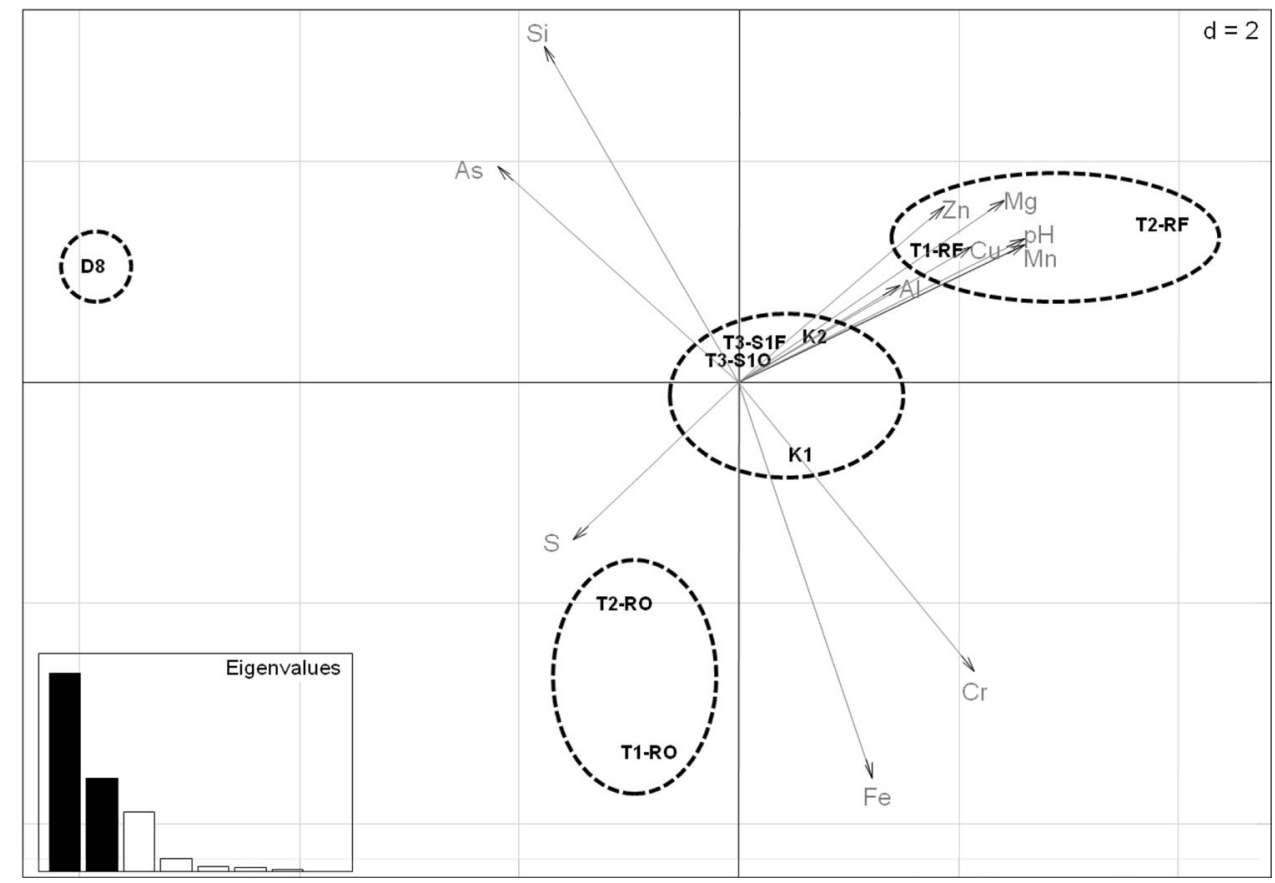


Table 1 Estimated OTU richness, diversity indices and estimated sample coverage for the nine 16S rRNA gene libraries

\begin{tabular}{|c|c|c|c|c|c|}
\hline Sampling stations & No. of normalized sequences & No. of OTUs ${ }^{\mathrm{a}}$ & Good's coverage ${ }^{b}$ & Shannon diversity $^{\mathrm{c}}$ & Chao1 richness \\
\hline T1-RF & 52671 & 137 & 100 & $3.32(3.31 ; 3.32)$ & $183(158 ; 241)$ \\
\hline T1-RO & 52671 & 147 & 100 & $2.86(2.85 ; 2.87)$ & $203(174 ; 264)$ \\
\hline T2-RF & 52671 & 127 & 100 & $3.57(3.56 ; 3.58)$ & $148(136 ; 180)$ \\
\hline $\mathrm{T} 2-\mathrm{RO}$ & 52671 & 143 & 100 & $3.23(3.23 ; 3.24)$ & $205(173 ; 272)$ \\
\hline T3-S1F & 52671 & 139 & 100 & $3.24(3.23 ; 3.25)$ & $178(157 ; 225)$ \\
\hline $\mathrm{T} 3-\mathrm{S} 1 \mathrm{O}$ & 52671 & 229 & 100 & $2.28(2.27 ; 2.30)$ & $286(258 ; 340)$ \\
\hline D8 & 52671 & 166 & 100 & $3.18(3.17 ; 3.19)$ & $201(182 ; 240)$ \\
\hline K1 & 52671 & 148 & 100 & $2.81(2.80 ; 2.83)$ & $178(161 ; 217)$ \\
\hline K2 & 52671 & 132 & 100 & $1.49(1.47 ; 1.51)$ & $163(145 ; 209)$ \\
\hline
\end{tabular}

Results are presented for the normalized data, randomly resampled to have an equal sample size

Values in brackets are $95 \%$ confidence intervals

a OTUs were defined at $97 \%$ cutoff

b Sum of probabilities of observed classes calculated as $(1-(n / N))$, where $n$ is the number of singleton sequences and $N$ is the total number of sequences

c Takes into account the number and evenness of species

than the observed number of OTUs, ranging from 148 for T2-RF to 286 for T3-S1O, suggesting the presence of a few more endemic taxa. The Shannon index, which measures the diversity of the microbial communities, varied slightly in the tailings (Table 1). The least microbial diversity was observed at K2 (1.49) and the highest at T2-RF (3.57).

\section{Taxonomic composition at Kettara pyrrhotite mine and spatial variation among the sampling sites}

In this study, the sequences of bacteria represented around 97\% of the total sequences compared to those of Archaea (only 12646 sequences, Table 2). For the bacteria, 313825 of the 461393 qualified reads $(68 \%)$ were assigned to a known phylum of bacteria (Table 2) at a confidence threshold of $80 \%$. For Archaea, only $47 \%$ of reads could be assigned to a known phylum. The largest proportion of unassigned sequences was mainly found in the coarse tailings and represented $85 \%$ of the unclassified sequences of bacteria (around 10\% for T3-S1F, 28\% for T3-S1O, $19 \%$ for K1 and 29\% for K2) and around 99\% of Archaea (mainly limited to T3-S1F sampling site). In all the samples, a total of 12 phyla of bacteria and one phylum of Archaea were identified. Sixty-seven percent of sequences of bacteria clustered in 4 phyla: Proteobacteria (29\%) and Firmicutes (25\%), followed by Actinobacteria (10\%) and Bacteroidetes (3\%, Table 2). The eight additional phyla were each represented by less than $1 \%$ of the sequences and belonged to Nitrospirae, Planctomycetes, Fusobacteria, Chloroflexi, Acidobacteria, Verrucomicrobia, DeinococcusThermus and Gemmatimonadetes. All the sequences of Archaea were assigned to the phylum of Euryarchaeota.
The OTUS were assigned to 87 genera of bacteria and two genera of Archaea (Table 3). The unclassified sequences of bacteria represented $43 \%$ of the total sequences of bacteria. Only 18 genera had sequences representing more than $1 \%$ of the total number of sequences of bacteria. The dominant bacteria genera were represented by sequences of Bacillus (representing around $8 \%$ of the total sequences of bacteria), followed by the genus Pseudomonas (5\%) and Corynebacterium (5\%). The unclassified sequences of Archaea represented 53\% of the total sequences of Archaea (Table 3). The two genera of Archaea, Methanobacterium and Methanosaeta represented, respectively, around 46 and $1 \%$ of the total sequences of Archaea.

Nonmetric MultiDimensional Scaling (NMDS) analysis was used to show the relationship between diversity patterns of microbial communities and environmental parameters (Fig. 3). The NMDS ordination showed a separation of the microbial communities along the first ordination axis, between the fine tailing (T1 and T2) and the secondary precipitate (D8), opposed to the coarse tailing (T3, K1 and K2). This analysis showed also that the main parameter discriminating our microbial communities was the concentration of $\mathrm{Al}\left(r^{2}=0.606, P=0.040\right.$, Fig. 3; Table $\mathrm{S} 2)$. Bacillus seemed more associated with the site T1-RO while Enterococcus and Burkholderia with the site D8 and Staphylococcus with the samples T2 (T2-RF and T2-RO).

\section{Discussion}

The aim of this study was to perform an in-depth characterization of the bacterial and archaeal diversity and their spatial distribution in nine different tailings of the Kettara 


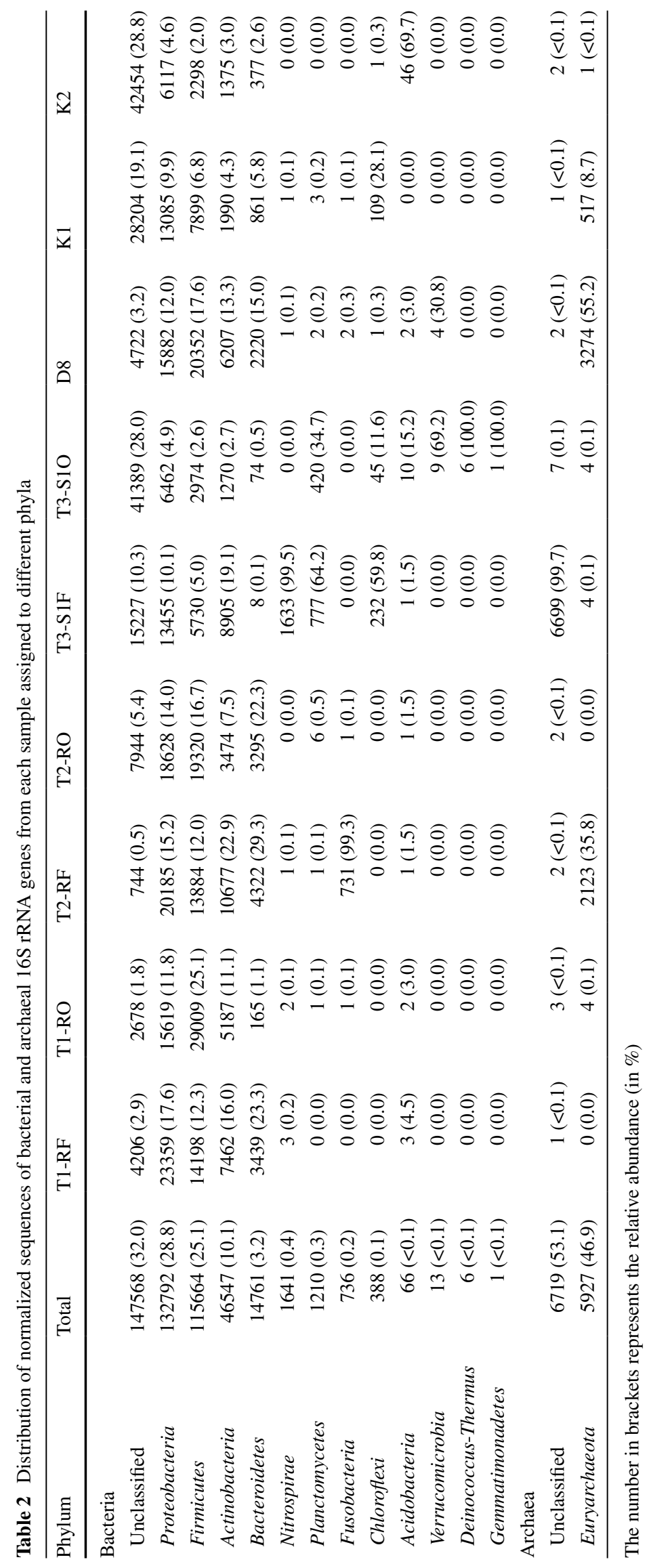


Table 3 Distribution of the relative abundance (in \%) of bacterial and archaeal 16S rRNA genes from each samples assigned to different genus

\begin{tabular}{|c|c|c|c|c|c|c|c|c|c|c|}
\hline Genus & Total & T1-RF & T1-RO & T2-RF & $\mathrm{T} 2-\mathrm{RO}$ & T3-S1F & $\mathrm{T} 3-\mathrm{S} 1 \mathrm{O}$ & D8 & K1 & $\mathrm{K} 2$ \\
\hline \multicolumn{11}{|l|}{ Bacteria } \\
\hline Unclassified & 43.3 & 8.3 & 6.9 & 4.1 & 7.7 & 10.9 & 21.9 & 2.9 & 15.6 & 21.6 \\
\hline Bacillus & 7.8 & 4.9 & 49.5 & 11.4 & 9.6 & 13.9 & 0.3 & 1.9 & 5.8 & 2.7 \\
\hline Pseudomonas & 5.3 & 17.4 & 14.1 & 9.8 & 13.1 & 4.8 & 1.9 & 11.0 & 16.4 & 11.4 \\
\hline Corynebacterium & 4.7 & 15.9 & 18.2 & 24.8 & 0.2 & 16.7 & 0.2 & 17.5 & 1.7 & 5.0 \\
\hline Staphylococcus & 3.5 & 21.4 & 0.4 & 39.1 & 26.0 & 2.2 & 0.1 & 7.6 & 3.1 & 0.1 \\
\hline Enterococcus & 2.8 & 0.4 & 0.5 & 0.2 & 18.1 & 0.2 & 0.6 & 64.2 & 12.1 & 3.7 \\
\hline Saccharibacillus & 2.4 & 29.6 & 3.7 & 9.9 & 22.4 & 2.6 & 0.2 & 25.7 & 5.6 & 0.2 \\
\hline Burkholderia & 2.0 & 0.2 & 0.1 & 11.0 & 2.0 & 0.1 & 0.2 & 74.5 & 10.0 & 1.9 \\
\hline Cloacibacterium & 2.0 & 22.1 & 0.1 & 34.1 & 20.9 & 0.0 & 0.5 & 15.1 & 6.4 & 0.8 \\
\hline Stenotrophomonas & 1.9 & 0.1 & 0.2 & 8.0 & 65.0 & 1.8 & 0.0 & 6.1 & 18.8 & 0.0 \\
\hline Acidiferrobacter & 1.8 & 0.2 & 0.3 & 0.2 & 0.2 & 66.2 & 29.8 & 0.3 & 0.2 & 2.6 \\
\hline Alcaligenes & 1.8 & 54.2 & 0.2 & 9.0 & 0.1 & 2.7 & 0.1 & 20.1 & 13.6 & 0.0 \\
\hline Agrobacterium & 1.7 & 14.2 & 36.2 & 21.8 & 0.2 & 23.8 & 0.1 & 0.1 & 2.6 & 0.9 \\
\hline Variovorax & 1.6 & 27.0 & 21.2 & 5.7 & 9.9 & 8.0 & 2.5 & 5.5 & 19.6 & 0.8 \\
\hline Micrococcus & 1.5 & 10.9 & 15.5 & 24.2 & 34.3 & 0.1 & 0.1 & 0.2 & 13.8 & 0.9 \\
\hline Phyllobacterium & 1.3 & 0.2 & 9.1 & 50.1 & 25.5 & 8.4 & 2.1 & 0.1 & 0.2 & 4.3 \\
\hline Acidiphilium & 1.1 & 0.2 & 0.2 & 0.3 & 0.3 & 0.3 & 49.3 & 0.2 & 23.8 & 25.4 \\
\hline Thermicanus & 1.0 & 8.4 & 35.4 & 0.2 & 17.5 & 0.0 & 0.3 & 33.6 & 4.2 & 0.4 \\
\hline Geobacillus & 1.0 & 1.3 & 0.2 & 0.2 & 83.2 & 0.0 & 0.3 & 14.6 & 0.1 & 0.1 \\
\hline Enterobacter & 0.9 & 2.4 & 72.5 & 0.2 & 16.6 & 2.8 & 3.1 & 0.3 & 2.1 & 0.0 \\
\hline Herbaspirillum & 0.7 & 0.2 & 6.7 & 0.2 & 60.2 & 12.1 & 0.2 & 0.1 & 19.0 & 1.4 \\
\hline Brevibacterium & 0.6 & 0.1 & 0.0 & 50.1 & 0.1 & 0.2 & 0.1 & 46.4 & 2.8 & 0.1 \\
\hline Alicyclobacillus & 0.6 & 0.3 & 0.5 & 0.4 & 0.3 & 0.1 & 58.1 & 0.4 & 27.5 & 12.4 \\
\hline Ruminococcus & 0.5 & 0.2 & 0.0 & 0.0 & 0.1 & 0.0 & 0.0 & 95.6 & 4.0 & 0.0 \\
\hline Lactobacillus & 0.4 & 99.7 & 0.0 & 0.0 & 0.1 & 0.0 & 0.0 & 0.0 & 0.1 & 0.0 \\
\hline Moraxella & 0.4 & 0.3 & 0.2 & 22.6 & 0.1 & 0.1 & 1.4 & 66.5 & 8.7 & 0.0 \\
\hline Acinetobacter & 0.4 & 0.3 & 13.8 & 39.1 & 0.3 & 33.6 & 1.7 & 0.3 & 6.7 & 4.3 \\
\hline Alcanivorax & 0.4 & 76.9 & 0.1 & 19.2 & 0.1 & 0.2 & 0.3 & 1.9 & 1.3 & 0.1 \\
\hline Escherichia & 0.4 & 7.2 & 29.8 & 60.9 & 0.2 & 0.1 & 0.2 & 0.0 & 0.6 & 1.1 \\
\hline Sphingobacterium & 0.4 & 55.6 & 0.1 & 0.1 & 0.1 & 0.1 & 0.7 & 22.6 & 4.2 & 16.6 \\
\hline Actinoallomurus & 0.4 & 0.1 & 0.1 & 0.1 & 0.1 & 99.2 & 0.1 & 0.1 & 0.2 & 0.1 \\
\hline Streptococcus & 0.4 & 57.7 & 0.3 & 0.9 & 36.2 & 0.1 & 1.4 & 0.8 & 0.2 & 2.5 \\
\hline Bifidobacterium & 0.4 & 0.2 & 0.1 & 0.1 & 35.4 & 0.0 & 0.1 & 55.7 & 0.2 & 8.2 \\
\hline Leptospirillum & 0.4 & 0.2 & 0.1 & 0.1 & 0.0 & 99.5 & 0.0 & 0.1 & 0.1 & 0.0 \\
\hline Brevundimonas & 0.3 & 0.7 & 0.0 & 98.1 & 0.0 & 0.0 & 0.0 & 1.2 & 0.0 & 0.0 \\
\hline Aeromonas & 0.3 & 0.1 & 0.1 & 0.0 & 11.9 & 0.1 & 0.0 & 73.1 & 0.0 & 14.7 \\
\hline Weissella & 0.3 & 0.0 & 0.0 & 0.1 & 0.1 & 0.1 & 0.1 & 99.5 & 0.1 & 0.0 \\
\hline Legionella & 0.3 & 0.2 & 0.0 & 99.3 & 0.1 & 0.0 & 0.2 & 0.1 & 0.2 & 0.1 \\
\hline Novosphingobium & 0.3 & 59.1 & 0.2 & 0.1 & 0.2 & 0.1 & 0.0 & 0.2 & 40.0 & 0.0 \\
\hline Cereibacter & 0.2 & 99.3 & 0.4 & 0.2 & 0.0 & 0.1 & 0.0 & 0.1 & 0.0 & 0.0 \\
\hline Tepidimonas & 0.2 & 32.6 & 0.2 & 61.2 & 0.1 & 0.1 & 0.6 & 5.2 & 0.0 & 0.0 \\
\hline Anaerococcus & 0.2 & 0.3 & 0.4 & 63.7 & 0.1 & 0.0 & 0.2 & 28.0 & 7.2 & 0.0 \\
\hline Tumebacillus & 0.2 & 0.1 & 0.0 & 0.0 & 0.1 & 0.1 & 0.5 & 99.2 & 0.0 & 0.0 \\
\hline Paracoccus & 0.2 & 69.7 & 0.2 & 29.7 & 0.1 & 0.0 & 0.0 & 0.1 & 0.0 & 0.1 \\
\hline Sulfobacillus & 0.2 & 0.1 & 0.4 & 0.0 & 0.3 & 1.3 & 96.4 & 0.3 & 0.5 & 0.9 \\
\hline Achromobacter & 0.2 & 0.6 & 16.5 & 67.5 & 0.0 & 0.3 & 15.0 & 0.0 & 0.0 & 0.1 \\
\hline Massilia & 0.2 & 0.1 & 91.9 & 0.0 & 0.0 & 0.3 & 0.1 & 0.0 & 0.1 & 7.4 \\
\hline \multicolumn{11}{|l|}{ Archaea } \\
\hline Unclassified & 53.1 & 0.0 & 0.1 & 16.8 & 0.0 & 53.0 & 0.1 & 25.9 & 4.1 & 0.0 \\
\hline
\end{tabular}


Table 3 continued

\begin{tabular}{lrccccccccc}
\hline Genus & Total & T1-RF & T1-RO & T2-RF & T2-RO & T3-S1F & T3-S1O & D8 & K1 & K2 \\
\hline Methanobacterium & 46.3 & 0.0 & 0.1 & 36.2 & 0.0 & 0.1 & 0.1 & 54.8 & 8.8 & 0.0 \\
Methanosaeta & 0.5 & 0.0 & 0.0 & 1.5 & 0.0 & 0.0 & 0.0 & 98.5 & 0.0 & 0.0 \\
\hline
\end{tabular}

Only genera comprising more than 700 sequences are presented

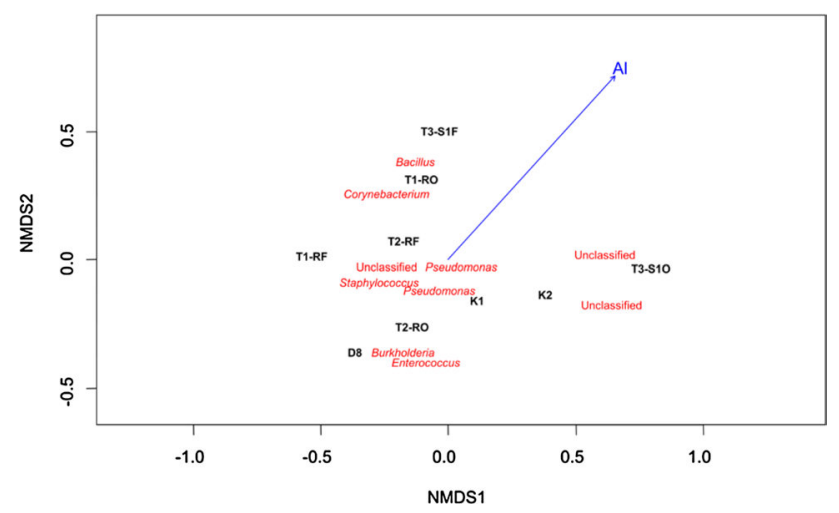

Fig. 3 Non-metric multidimensional scaling (NMDS) ordination plot derived from pairwise matrice distances of microbial communities for each sampling site. The stress values were $<0.2$ which indicates that these data were well-represented by the two dimensional representation. The angle and length of the vector indicate the direction and strength of the variable. Arrows are the projections of possible explanation variables obtained by vector fitting. Only correlations with $p<0.05$ were indicated. The $r^{2}$ correlation coefficient and the $p$ values are presented in Table S2. The 10 most abundant OTUs were also presented

pyrrhotite mine producing AMD, to better understand the potential role of microorganisms in the formation of mine drainage. Many studies have investigated the microbial and community structure of sulfidic mine waste (Schippers et al. 2010; Chen et al. 2013; Liu et al. 2014), but most of them mainly sampled pyrite tailings and little is known about the microbial communities inhabiting pyrrhotite mine tailings (Schippers et al. 2007; Kock and Schippers 2008; Korehi et al. 2014). To our knowledge, this is the first investigation of the microbial structure of pyrrhotite-rich mine tailings using next-generation sequencing.

\section{Microbial diversity and taxonomic composition of the sediments}

This work has revealed a higher microbial diversity in acid generating mine tailings than those reported in studies based on clone library analyses (Diaby et al. 2007; Tan et al. 2008; Huang et al. 2011) but a lower diversity than those using next-generation sequencing (Chen et al. 2013; Liu et al. 2014). The rarefaction curves and the coverage suggested an identification of the majority of the microbial communities. The high level of sequences of bacteria and Archaea that could not be classified at the phylum level suggested that many novel microorganisms were also detected.

More than 69 genera of bacteria had a number of sequences representing less than $1 \%$ of the total number of sequences of bacteria, i.e., corresponding to the "rare biosphere". The ecological and functional roles of this rare biosphere, encountered in quite large proportions in most studies since the arrival of next-generation sequencing, are still not well understood (Galand et al. 2009). It is hypothesized that such organisms could become dominant under changing environmental conditions and that their functional redundancy could allow biogeochemical processes to be maintained (Bachy and Worden 2014). Other studies question the accuracy of OTU richness estimates resulting from high-throughput sequencing, which could correspond to sequencing errors or could be generated by the use of inappropriate algorithms (Huse et al. 2010).

The dominant bacteria genera were related to Bacillus (representing around $8 \%$ of the total sequences of bacteria), followed by the genus Pseudomonas (5\%), Corynebacterium (5\%) and Staphylococcus (4\%). These genera have already been detected in mine dumps or heaps, sometimes as dominant populations (Schippers et al. 2010; Chen et al. 2013).

\section{Ecological role and potential impact on the environment}

Bioleaching of metal sulfides is performed by a diverse group of microorganisms, but metal sulfide dissolution is mainly mediated by $\mathrm{Fe}(\mathrm{III})$ and to a certain extent by sulfur-oxidizing communities thanks to their capacity to reduce the accumulation of sulfur on the surface of metal sulfides and through the generation of protons that dissolve acid-soluble metal sulfides like pyrrhotite (Vera et al. 2013).

Concerning the biogeochemical cycling of iron in the Kettara mine, two microorganisms well known for their leading role in the bioleaching and formation of AMD, were identified: Acidiferrobacter and Leptospirillum representing, respectively, $2 \%$ and less than $0.4 \%$ of the total bacterial sequences. Acidiferrobacter, formerly called "Thiobacillus ferrooxidans $\mathrm{m}-1$ ", is an acidophilic ironoxidizing bacterium (Hallberg et al. 2011). Although the majority of Alicyclobacillus species mainly utilize organic 
compounds, different species are also able to oxidize ferrous iron for growth, including Alicyclobacillus ferrooxydans, A. disulfidooxidans and A. tolerans (Karavaiko et al. 2005; Jiang et al. 2008). This genus, forming endospores under adverse environmental or nutritional conditions, representing around $1 \%$ of the total sequences of bacteria identified in Kettara mine, is known as leaching bacteria (Vera et al. 2013). Another acidophilic and spore forming genus, known for its active role in the oxidation of sulfide minerals is the genus Sulfobacillus containing many isolates identified as iron oxidizers (Norris et al. 1996; Justice et al. 2014). This genus represented $0.2 \%$ of the sequences identified in Kettara mine. Some species of Pseudomonas, like P. stutzeri (Weber et al. 2006; Muehe et al. 2009) or Pseudomonas sp. GE-1 forming ferrihydrite (Xiu et al. 2015), are able to oxidize iron. Other genera like Paracoccus, representing $0.2 \%$ of the total bacteria identified in Kettara mine such as Paracoccus ferrooxidans, was also shown to oxidize iron (Kumaraswamy et al. 2006).

$\mathrm{Fe}(\mathrm{III})$-reducing microorganisms are known to dissolve $\mathrm{Fe}(\mathrm{III})$ (hydr)oxides, thereby releasing adsorbed or precipitated metals (Schippers et al., 2010). Acidiferrobacter is known to grow by ferric iron respiration (Hallberg et al., 2011) like some strains of Sulfobacillus (Sulfobacillus thermosulfidooxidans, Sulfobacillus acidophilus, Bridge and Johnson 1998; Justice et al. 2014). Many other genera are involved in the reduction of Fe(III) including Alicyclobacillus (Weber et al. 2006; A. tolerans, Karavaiko et al. 2005); Bacillus (Schippers et al. 2010 including Bacillus infernus, Weber et al. 2006); Pseudomonas (Schippers et al. 2010, Pseudomonas stutzeri, Wang et al. 2014a); Acidiphilium (an acidophilic genus quite common in AMD that represented $1 \%$ of the total sequence of bacteria in Kettara mine, like Acidiphilium acidophilum, Johnson and Bridge 2002; Weber et al. 2006) or Aeromonas (Aeromonas hydrophila, Weber et al. 2006; Ventura et al. 2015). This species, which represented $0.3 \%$ of the sequences of bacteria identified at Kettara mine, is able to use different $\mathrm{Fe}(\mathrm{III})$-oxyhydroxides, some weathering compounds commonly retrieved at mine sites like ferrihydrite, or jarosite as sole source of iron (Garcia Balboa et al. 2010).

Numerous microorganisms are known to be implicated in the redox transformation of sulfur, using elemental sulfur or inorganic sulfur compounds as electron donors or acceptors (Dopson and Johnson 2012). In the Kettara tailings, different populations able to oxidize the reduced inorganic sulfur compounds were retrieved, including Acidiferrobacter (Hallberg et al. 2011); Sulfobacillus (Norris et al. 1996; Justice et al. 2014); Alicyclobacillus (A. disulfidooxidans or A. ferrooxidans, Karavaiko et al. 2005; Jiang et al. 2008); Pseudomonas (Turner 1954, P. stutzeri, Sorokin et al. 1999; Mahmood et al. 2009; Pseudomonas sp. C27, Xu et al. 2016) or Paracoccus (P. denitrificans, Friedrich and
Mitrenga 1981; P. versutus (formerly Thiobacillus versutus, Katayama et al. 1995), P. ferrooxidans (Kumaraswamy et al. 2006) or P. pantotrophus, Vikromvarasiri et al. 2015). Chemolithotrophic growth with elemental sulfur or thiosulphate as energy source had also been observed in the genus Acidiphilium but differs from species to species (Okamura et al. 2015). Species of the genus Alcaligenes (representing $2 \%$ in the Kettara tailings) can also grow autotrophically by using sulfur compounds as sole energy sources (Anandham et al. 2008; Luo et al. 2013). Other species, less encountered in mine environments, can also oxidize reduced inorganic sulfur compounds like Bacillus (Bacillus pumilus, Bacillus subtilis, Bacillus megaterium) and Micrococcus spp. (Behera et al. 2014) or Corynebacterium (Omori et al. 1992). Genus of archaea like Methanobacterium, possess also the capacity to grow with sulfide or elemental sulfur (Zeikus and Wolfe 1972; Bhatnagar et al. 1984).

Microorganisms like Clostridium (representing less than $0.1 \%$ of total bacteria at Kettara mine) appear also able to reduce polysulfide to hydrogen sulfide (Takahashi et al. 2010), such as Clostridium sulfidigenes, a mesophilic, thiosulfate and sulfur reducing bacterium (Sallam and Steinbüchel 2009).

Among all the toxic elements present at the Kettara site, arsenic is of particular concern due to the serious environmental and health impact of this metalloid on living organisms (Mandal and Suzuki 2002; Abdul et al. 2015). Along with abiotic processes, the activity of As transforming microorganisms has a major influence on the behavior of this element because different As species present differences in their toxicity, solubility, mobility, and bioavailability depending on its state of oxidation (Macur et al. 2004; Sarkar et al. 2014). For example, As(III) can be oxidized in the less soluble and less toxic form $\mathrm{As}(\mathrm{V})$, thus redox transformations of As are of great importance to predict its fate in the environment (Oremland and Stolz 2003; Yamamura and Amachi 2014). In the pyrrhotite-rich Kettara tailings, containing high concentration of arsenic (up to $344 \mathrm{mg} \mathrm{kg}^{-1}$ ), we have identified many genera, which contained species known to oxidize As. It is the case of the two predominant populations in Kettara, Bacillus (Fisher and Hollibaugh 2008, Bacillus firmus, Bachate et al. 2013) and Pseudomonas (Turner 1954, P. stutzeri, P. arsenitoxidans or P. arsenoxydans, etc., Das et al. 2014; Bahar et al. 2013a). It is also the case of different species, representing around $2 \%$ of sequences of bacteria identified at Kettara mine, such as Stenotrophomonas (Bahar et al. 2012, 2013a); Agrobacterium (Santini et al. 2000, Agrobacterium tumefaciens, Macur et al. 2004); Variovorax (Variovorax paradoxus, Macur et al. 2004; Bahar et al. 2013b); Burkholderia (Burkholderia cepacia, Campos et al. 2009) or Alcaligenes (Osborne and Ehrlich (1976), 
including Alcaligenes faecalis, Bahar et al. 2013a). Minor species, representing less than $0.4 \%$ at Kettara mine, had also this capacity, like Acinetobacter (Chang et al. 2011; Das et al. 2014); Achromobacter (Turner 1954; Bachate et al. 2012); Arthrobacter (Duan et al. 2013) or Brevibacillus (Brevibacillus brevis, Banerjee et al. 2013).

A wide variety of microorganisms are also able to reduce As, which could have implications for the remobilization of As, including Bacillus, able to respire this metalloid like Bacillus arsenicoselenatis or Bacillus selenitireducens (Blum et al. 1998); Agrobacterium (Agrobacterium tumefaciens, Macur et al. 2004); Enterobacter sp. (representing around $3 \%$ of the total bacteria identified at Kettara mine, Liao et al. 2011); Acinetobacter (Paul et al. 2014); Escherichia (representing around 0.4\% of the total bacteria identified at Kettara, Bahar et al. 2013a) or Clostridium sp. (Stolz et al. 2006).

Some species are also able to methylate As or to produce arsine, like the archaea Methanobacterium bryantii or Methanobacterium formicium producing methylated arsines and arsine, while Clostridium collagenovorans produces trimethyl arsine (Stolz et al. 2006). According to Wang et al. (2014b), species of genus like Escherichia and Corynebacterium sp., produce dimethylarsine; Enterobacter sp., Achromobacter sp. or Aeromonas sp. produce mono and dimethylarsine; Alcaligenes sp. produce mono-, dimethylarsine and arsine and Pseudomonas sp. produce mono-, di- and trimethylarsine and arsine. Microbial volatilization of arsines in the environment could play an important role in the biogeochemical cycling of As, and could be an interesting method for arsenic bioremediation, like bio-volatilization (Wang et al. 2014b).

Autotrophic and heterotrophic microorganisms are also important in these extreme environments. Indeed, autotrophic iron- and sulfur-oxidizing microorganisms that fix inorganic carbon provide organic materials used as growth substrates by heterotrophic populations (Johnson and Hallberg 2008) like Acidiferrobacter, an obligate autotroph and facultative anaerobe that fixes inorganic carbon and could also assimilate dinitrogen for growth (Hallberg et al. 2011). Heterotrophic bacteria that degrade organic compounds are also important in this environment, because they enable the continued growth of autotrophic $\mathrm{Fe}(\mathrm{II})$ and sulfur-oxidizing bacteria, which are often sensitive to the presence of this type of compound (Schippers et al. 2010; Hallberg 2010). Many microorganisms including Bacillus, Pseudomonas, Acidiphilium, Enterobacter, Alicyclobacillus, Acinetobacter or Sulfobacillus are known for their ability to oxidize organic carbon and are found in mine tailings and dumps (Schippers et al. 2010; Sanchez Andrea et al. 2011).

\section{Spatial variation in microbial communities presents in the mine tailings of Kettara}

According to Hakkou et al. (2008a), the main sulfide minerals were pyrrhotite and pyrite in both unweathered and oxidized Kettara tailings. The most abundant gangue minerals are chlorite-serpentine, quartz, talc, and goethite (most likely secondary phase). Muscovite and albite are present in trace proportions and carbonates (calcite) occur in very negligible quantities. Trace amounts of jarosite were also observed.

Principal component analysis revealed substantial differences in tailings microbial community composition with four groups identified: the secondary precipitates; the oxidized parts of the fine tailings; the unoxidized parts of the fine tailings and the coarse tailings. The alteration process was more intense in the coarse tailings of the dyke than in the tailings pond with an extensive oxidation front through the upper $75 \mathrm{~cm}$ in the coarse tailings compared to $5-15 \mathrm{~cm}$ in the tailings dam. Indeed, coarse tailings facilitate oxygen access and increase oxidation of sulfides due to their large particle size, contrary to the tailings pond where alteration was limited, due to the presence of a hardpan layer formed at the surface of tailings pond (Hakkou et al. 2008a). The principal $\mathrm{Fe}$ (II) and sulfur-oxidizing bacteria, well known for metal sulfide oxidation were mainly present in the coarse tailings, like Acidiferrobacter representing, in the dyke trench T3, $66 \%$ in T3-S1F and 30\% in T3-S1O; Alicyclobacillus $(58 \%$ in T3-S1O, 27\% in K1 and 12\% in K2; Leptospirillum (more than 99\% in T3-S1F) or Sulfobacillus (96\% in T3-S1O).

Our results highlighted also a quite different microbial community, compared to other sulfuric mine tailings producing AMD with our 4 most abundant populations similar to Bacillus, Pseudomonas, Corynebacterium and Staphylococcus and not to the well-known iron-oxidizing populations. Studies of microbial population in acidic mine tailings are not numerous, but many of them have identified the predominance of typical leaching bacteria such as Acidithiobacillus, Leptospirillum, Sulfobacillus or Ferroplasma. It is the case for different mine tailings containing mainly pyrite; a lead and zinc mine in China (Huang et al. 2011; Chen et al. 2013); a massive copper tailing in China (Liu et al. 2014); a copper and molybdenum porphyry mine in Chile (Diaby et al. 2007) or an abandoned semi-arid lead-zinc mine tailing site in USA (Mendez et al. 2008). Korehi et al. (2014) obtained similar results in 3 sulfidic mine tailings: a $\mathrm{Pb}, \mathrm{Zn}$ and $\mathrm{Ag}$ mine containing pyrite and arsenopyrite in a temperate zone in Germany; a $\mathrm{Zn}$ and $\mathrm{Cu}$ mine dominated by pyrite in a cold and humid climate in Sweden and also in a former $\mathrm{Ni}$, $\mathrm{Cu}, \mathrm{Zn}$ and Co mine in Botswana containing mainly pyrrhotite in a hornblende and feldspar as gangue minerals in semi-arid climate, thus quite similar to our conditions 
(Schippers et al. 2007; Kock and Schippers 2008). However, three of our four dominant bacterial population (Pseudomonas, Corynebacterium and Staphylococcus), were also the dominant genera in the extremely acidic part of a mine tailings of the lead and zinc mine in China, present in a warm and humid subtropical climate (Huang et al. 2011; Chen et al. 2013). The metallic minerals in this mine are pyrite, sphalerite, galena, chalcopyrite, tetrahedrite and magnetic pyrite and the major gangue minerals are calcite, dolomite and quartz (Han et al. 2012).

$\mathrm{pH}$ seemed to be often the most important factor shaping the microbial communities in mine tailings (Korehi et al. 2014; Chen et al. 2013; Liu et al. 2014). However, in our study, NMDS showed that Al was the main parameter discriminating our microbial communities (Fig. 3). In the Kettara mine, concentration of $\mathrm{Al}$ is very important in mine tailing (from 10407 to $74557 \mathrm{mg} \mathrm{kg}^{-1}$ ) and in AMD (from 730 to $4170 \mathrm{mg}^{-1}$ ). This element is known to be toxic for some microorganisms when present in high concentrations, competing with metabolism of iron and magnesium, and binding to DNA, membranes or cell walls (Pina and Cervantes 1996; Auger et al. 2013).

The generation, mobility, and attenuation of AMD involve complex processes governed by a combination of physical, chemical, but also biological factors (Simate and Ndlovu 2014). Acid mine drainage (AMD) is considered as one of the main causes of water pollution in many countries that have historic or current mining activities and this phenomenon is particularly problematic in semi-arid areas with water shortage. In Kettara mine, sequences related to Bacillus, Pseudomonas, Corynebacterium and Staphylococcus were identified as the dominant genera. However, many species are also related to genera known to play a key role in $\mathrm{Fe}$ and $\mathrm{S}$ cycle implicated in the oxidation of mineral sulfides but also in As and $\mathrm{C}$ cycles, helping us to gain a deeper understanding of the functioning of this ecosystem that produce intermittent AMD. To our knowledge, this is one of the first descriptions of microbial communities in a pyrrhotite mine using high-throughput sequencing, and the first description of the microbial community at Kettara mine. Such knowledge of microbial populations is useful to secure reactive mine tailings and will also help for the further development of waste management and bioremediation strategies.

Acknowledgements The authors thank the International Research Chairs Initiative funded by the International Development Research Centre (IDRC), Canada, and by the Canada Research Chairs program and the IRD (Institut de Recherche pour le Développement) for supporting this research.

\section{Compliance with ethical standards}

Conflict of interest The authors declare that they have no conflict of interest.

\section{References}

Abdul SM, Jayasinghe SS, Chandana EPS, Jayasumana C et al (2015) Arsenic and human health effects: a review. Environ Toxicol Pharmacol 40:828-846

Akcil A, Koldas S (2006) Acid mine drainage (AMD): causes, treatment and case studies. J Clean Prod 14:1139-1145

Anandham R, Indiragandhi P, Madhaiyan M, Ryu KY et al (2008) Chemolithoautotrophic oxidation of thiosulfate and phylogenetic distribution of sulfur oxidation gene (soxB) in rhizobacteria isolated from crop plants. Res Microbiol 159:579-589

Auger C, Han S, Appanna VP, Thomas SC, Ulibarri G, Appanna VD (2013) Metabolic reengineering invoked by microbial systems to decontaminate aluminum: implications for bioremediation technologies. Biotechnol Adv 31:266-273

Babi K, Asselin H, Benzaazoua M (2015) Stakeholders' perceptions of sustainable mining in Morocco: a case study of the abandoned Kettara mine. Extr Ind Soc 1:185-192

Bachate SP, Khapare RM, Kodam KM (2012) Oxidation of arsenite by two $\beta$-proteobacteria isolated from soil. Appl Microbiol Biotechnol 93:2135-2145

Bachate SP, Nandre VS, Ghatpande NS, Kodam KM (2013) Simultaneous reduction of $\mathrm{Cr}(\mathrm{VI})$ and oxidation of As(III) by Bacillus firmus TE7 isolated from tannery effluent. Chemosphere 90:2273-2278

Bachy C, Worden AZ (2014) Microbial ecology: finding structure in the rare biosphere. Curr Biol 24:R315-R317

Bahar MM, Megharaj M, Naidu R (2012) Arsenic bioremediation potential of new arsenic oxidizing bacterium Stenotrophomonas sp. MM-7 isolated from soil. Biodegradation 23:803-812

Bahar MM, Megharaj M, Naidu R (2013a) Bioremediation of arsenic-contaminated water: recent advances and future prospects. Water Air Soil Pollut 224:1722

Bahar MM, Megharaj M, Naidu R (2013b) Kinetics of arsenite oxidation by Variovorax sp. MM-1 isolated from a soil containing low arsenic and identification of arsenite oxidase gene. J Hazard Mater 262:997-1003

Banerjee S, Majumdar J, Samal AC, Bhattachariya P et al (2013) Biotransformation and bioaccumulation of arsenic by Brevibacillus brevis isolated from arsenic contaminated region of West Bengal. IOSR J Environ Sci Toxicol Food Technol 3:1-10

Bates ST, Berg-Lyons D, Caporaso JG et al (2011) Examining the global distribution of dominant archaeal populations in soil. ISME J 5:908-917

Behera BC, Patra M, Dutta SK, Thatoi HN (2014) Isolation and characterisation of sulphur oxidising bacteria from mangrove soil of Mahanadi River Delta and their sulphur oxidising ability. J Appl Environ Microbiol 2:1-5

Bhatnagar L, Henriquet M, Zeikus JG, Aubert JP (1984) Utilization of mercapto-2-ethanol as a medium reductant for determination of the metabolic response of methanogens towards inorganic sulfur compounds. FEMS Microbiol Lett 22:155-158

Blum JS, Bindi AB, Buzelli J, Stolz JF, Oremland RS (1998) Bacillus arsenicoselenatis, sp. nov., and Bacillus selenitireducens, sp. nov.: two haloalkaliphiles from Mono Lake, California that respire oxyanions. Arch Microbiol 171:19-30

Bridge TAM, Johnson DB (1998) Reduction of soluble iron and reductive dissolution of ferric iron-containing minerals by moderately thermophilic iron-oxidizing bacteria. Appl Environ Microbiol 64:2181-2186

Campos VL, Escalante G, Yañez J, Zaror CA et al (2009) Isolation of arsenite-oxidizing bacteria from a natural biofilm associated to volcanic rocks of Atacama Desert, Chile. J Basic Microbiol 49:S93-S97 
Caporaso JG, Lauber CL, Walters WA, Berg-Lyons D et al (2011) Global patterns of $16 \mathrm{~S}$ rRNA diversity at a depth of millions of sequences per sample. Proc Natl Acad Sci 108:4516-4522

Chang J-S, Lee J-H, Kim I-S (2011) Bacterial aox genotype from arsenic contaminated mine to adjacent coastal sediment: evidences for potential biogeochemical arsenic oxidation. J Hazard Mater 193:233-242

Chen LX, Li JT, Chen YT, Huang LN et al (2013) Shifts in microbial community composition and function in the acidification of a lead/zinc mine tailings. Environ Microbiol 15:2431-2444

Das S, Jean J-S, Kar S, Chou M-L et al (2014) Screening of plant growth-promoting traits in arsenic-resistant bacteria isolated from agricultural soil and their potential implication for arsenic bioremediation. J Hazard Mater 272:112-120

Diaby N, Dold B, Pfeifer HR, Holliger C, Johnson DB, Hallberg KB (2007) Microbial communities in a porphyry copper tailings impoundment and their impact on the geochemical dynamics of the mine waste. Environ Microbiol 9:298-307

Dopson M, Johnson DB (2012) Biodiversity, metabolism and applications of acidophilic sulfur-metabolizing microorganisms. Environ Microbiol 14:2620-2631

Duan M, Wang Y, Xie X, Su C et al (2013) Arsenite oxidizing bacterium isolated from high arsenic groundwater aquifers from Datong Basin, Northern China. Proc Earth Planet Sci $7: 232-235$

Edgar RC, Haas BJ, Clemente JC, Quince C et al (2011) UCHIME improves sensitivity and speed of chimera detection. Bioinformatics 27:2194-2200

Fisher J, Hollibaugh JT (2008) Selenate-dependent anaerobic arsenite oxidation by a bacterium from Mono Lake, California. Appl Environ Microbiol 74:2588-2594

Friedrich CG, Mitrenga G (1981) Oxidation of thiosulfate by Paracoccus denitrificans and other hydrogen bacteria. FEMS Microbiol Lett 10:209-212

Galand PE, Casamayor EO, Kirchman DL, Lovejoy C (2009) Ecology of the rare microbial biosphere of the Arctic Ocean. Proc Natl Acad Sci USA 106:22427-22432

Garcia Balboa C, Bedoya IC, González F, Blázquez ML, Muñoz JA, Ballester A (2010) Bio-reduction of Fe(III) ores using three pure strains of Aeromonas hydrophila, Serratia fonticola and Clostridium celerecrescens and a natural consortium. Biores Technol 101:7864-7871

Hakkou R, Benzaazoua M, Bussière B (2008a) Acid mine drainage at the abandoned Kettara mine (Morocco): 1. Environmental characterization. Mine Water Environ 27:145-159

Hakkou R, Benzaazoua M, Bussière B (2008b) Acid mine drainage at the abandoned Kettara mine (Morocco): 2. Mine waste geochemical behavior. Mine Water Environ 27:160-170

Hallberg KB (2010) New perspectives in acid mine drainage microbiology. Hydrometallurgy 104:448-453

Hallberg KB, Hedrich S, Johnson DB (2011) Acidiferrobacter thiooxydans, gen. nov. sp. nov.; an acidophilic, thermo-tolerant, facultatively anaerobic iron-and sulfur-oxidizer of the family Ectothiorhodospiraceae. Extremophiles 15:271-279

Han Y, Wang JB, Zhu XY, Guo NN (2012) Stable isotope and REE geological and geochemical characteristics of the calcite in the Fankou Zinc-Lead deposit, Guangdong Province, China. In Adv Mater Res 524:205-212

Huang LN, Zhou WH, Hallberg KB, Wan CY, Li J, Shu WS (2011) Spatial and temporal analysis of the microbial community in the tailings of a $\mathrm{Pb}-\mathrm{Zn}$ mine generating acidic drainage. Appl Environ Microbiol 77:5540-5544

Huse SM, Welch DM, Morrison HG, Sogin ML (2010) Ironing out the wrinkles in the rare biosphere through improved OTU clustering. Environ Microbiol 12:1889-1898
Jiang CY, Liu Y, Liu YY, You XY, Guo X, Liu SJ (2008) Alicyclobacillus ferrooxydans sp. nov., a ferrous-oxidizing bacterium from solfataric soil. Int J Syst Evol Microbiol 58:2898-2903

Johnson DB, Bridge TAM (2002) Reduction of ferric iron by acidophilic heterotrophic bacteria: evidence for constitutive and inducible enzyme systems in Acidiphilium spp. J Appl Microbiol 92:315-321

Johnson DB, Hallberg KB (2008) Carbon, iron and sulfur metabolism in acidophilic micro-organisms. Adv Microb Physiol $54: 201-255$

Justice NB, Norman A, Brown CT, Singh A, Thomas BC, Banfield JF (2014) Comparison of environmental and isolate Sulfobacillus genomes reveals diverse carbon, sulfur, nitrogen, and hydrogen metabolisms. BMC Genomics 15:1107

Karavaiko GI, Bogdanova TI, Tourova TP, Kondrat'eva TF et al (2005) Reclassification of 'Sulfobacillus thermosulfidooxidans subsp thermotolerans' strain K1 as Alicyclobacillus tolerans sp. nov. and Sulfobacillus disulfidooxidans Dufresne et al 1996 as Alicyclobacillus disulfidooxidans comb. nov., and emended description of the genus Alicyclobacillus. Int J Syst Evol Microbiol 55:941-947

Katayama Y, Hiraishi A, Kuraishi H (1995) Paracoccus thiocyanatus sp. nov., a new species of thiocyanate-utilizing facultative chemolithotroph, and transfer of Thiobacillus versutus to the genus Paracoccus as Paracoccus versutus comb. nov. with emendation of the genus. Microbiology 141:1469-1477

Khalil K, Hanich L, Bannari A, Zouhri L et al (2013) Assessment of soil contamination around an abandoned mine in a semi-arid environment using geochemistry and geostatistics: pre-work of geochemical process modeling with numerical models. J Geochem Explor 125:117-129

Kock D, Schippers A (2008) Quantitative microbial community analysis of three different sulfidic mine tailing dumps generating acid mine drainage. Appl Environ Microbiol 74:5211-5219

Korehi H, Blöthe M, Schippers A (2014) Microbial diversity at the moderate acidic stage in three different sulfidic mine tailings dumps generating acid mine drainage. Res Microbiol 165:713-718

Kozich JJ, Westcott SL, Baxter NT, Highlander SK, Schloss PD (2013) Development of a dual-index sequencing strategy and curation pipeline for analyzing amplicon sequence data on the MiSeq Illumina sequencing platform. Appl Environ Microbiol 79:5112-5120

Kumaraswamy R, Sjollema K, Kuenen G, Van Loosdrecht M, Muyzer G (2006) Nitrate-dependent [Fe(II) EDTA] ${ }^{2-}$ oxidation by Paracoccus ferrooxidans sp. nov., isolated from a denitrifying bioreactor. Syst Appl Microbiol 29:276-286

Lghoul M, Teixidó T, Peña JA, Hakkou R, Kchikach A, Guérin R et al (2012) Electrical and seismic tomography used to image the structure of a tailings pond at the abandoned Kettara mine, Morocco. Mine Water Environ 31:53-61

Lghoul M, Maqsoud A, Hakkou R, Kchikach A (2014) Hydrogeochemical behavior around the abandoned Kettara mine site, Morocco. J Geochem Explor 144:456-467

Liao VHC, Chu YJ, Su YC, Hsiao SY, Wei CC, Liu CW et al (2011) Arsenite-oxidizing and arsenate-reducing bacteria associated with arsenic-rich groundwater in Taiwan. J Contam Hydrol 123:20-29

Liu J, Hua ZS, Chen LX, Kuang JL, Li SJ, Shu WS, Huang LN (2014) Correlating microbial diversity patterns with geochemistry in an extreme and heterogeneous environment of mine tailings. Appl Environ Microbiol 80:3677-3686

Luo J, Tian G, Lin W (2013) Enrichment, isolation and identification of sulfur-oxidizing bacteria from sulfide removing bioreactor. J Environ Sci 25:1393-1399 
Macur RE, Jackson CR, Botero LM, Mcdermott TR, Inskeep WP (2004) Bacterial populations associated with the oxidation and reduction of arsenic in an unsaturated soil. Environ Sci Technol 38:104-111

Mahmood Q, Zheng P, Hu B, Jilani G, Azim MR, Wu D, Liu D (2009) Isolation and characterization of Pseudomonas stutzeri QZ1 from an anoxic sulfide-oxidizing bioreactor. Anaerobe 15:108-115

Mandal BK, Suzuki KT (2002) Arsenic round the world: a review. Talanta 58:201-235

Mathieu C, Pieltain F (2003) Analyse chimique des sols. In: Méthode choisis. Ed Lavoisier, Tec and Doc

Mendez MO, Neilson JW, Maier RM (2008) Characterization of a bacterial community in an abandoned semiarid lead-zinc mine tailing site. Appl Environ Microbiol 74:3899-3907

Muehe EM, Gerhardt S, Schink B, Kappler A (2009) Ecophysiology and the energetic benefit of mixotrophic Fe(II) oxidation by various strains of nitrate-reducing bacteria. FEMS Microbiol Ecol 70:335-343

Needleman SB, Wunsch CD (1970) A general method applicable to the search for similarities in the amino acid sequence of two proteins. J Mol Biol 48:443-453

Norris PR, Clark DA, Owen JP, Waterhouse S (1996) Characteristics of Sulfobacillus acidophilus sp. nov. and other moderately thermophilic mineral-sulphide-oxidizing bacteria. Microbiology 142:775-783

Okamura K, Kawai A, Wakao N, Yamada T, Hiraishi A (2015) Acidiphilium iwatense sp. nov., isolated from an acid mine drainage treatment plant, and emendation of the genus Acidiphilium. Int J Syst Evol Microbiol 65:42-48

Omori T, Monna LISA, Saiki Y, Kodama T (1992) Desulfurization of dibenzothiophene by Corynebacterium sp. strain SY1. Appl Environ Microbiol 58:911-915

Oremland RS, Stolz JF (2003) The ecology of arsenic. Science 300:939-944

Osborne FH, Ehrlich HL (1976) Oxidation of arsenite by a soil isolate of Alcaligenes. J Appl Microbiol 41:295-305

Paul D, Poddar S, Sar P (2014) Characterization of arsenite-oxidizing bacteria isolated from arsenic-contaminated groundwater of West Bengal. J Environ Sci Health Part A-Toxic/Hazard Subst Environ Eng 49:1481-1492

Pina RG, Cervantes C (1996) Microbial interactions with aluminium. BioMetals 9:311-316

R Development Core Team (2012) R: a language and environment for statistical computing. R Foundation for Statistical Computing, Vienna. http://www.R-project.org

Rawlings DE, Johnson DB (2007) The microbiology of biomining: development and optimization of mineral-oxidizing microbial consortia. Microbiology 153:315-324

Sallam A, Steinbüchel A (2009) Clostridium sulfidigenes sp. nov., a mesophilic, proteolytic, thiosulfate-and sulfur-reducing bacterium isolated from pond sediment. Int J Syst Evol Microbiol 59:1661-1665

Sanchez Andrea I, Rodriguez N, Amils R, Sanz JL (2011) Microbial diversity in anaerobic sediments at Rio Tinto, a naturally acidic environment with a high heavy metal content. Appl Environ Microbiol 77:6085-6093

Santini JM, Sly LI, Schnagl RD, Macy JM (2000) A new chemolithoautotrophic arsenite-oxidizing bacterium isolated from a gold mine: phylogenetic, physiological, and preliminary biochemical studies. Appl Environ Microbiol 66:92-97

Sarkar A, Kazy KS, Sar P (2014) Studies on arsenic transforming groundwater bacteria and their role in arsenic release from subsurface sediment. Environ Sci Pollut Res 21:8645-8662

Schippers A, Sand W (1999) Bacterial leaching of metal sulfides proceeds by two indirect mechanisms via thiosulfate or via polysulfides and sulfur. Appl Environ Microbiol 65:319-321
Schippers A, Kock D, Schwartz M, Böttcher ME, Vogel H, Hagger M (2007) Geomicrobiological and geochemical investigation of a pyrrhotite-containing mine waste tailings dam near SelebiPhikwe in Botswana. J Geochem Explor 92:151-158

Schippers A, Breuker A, Blazejak A, Bosecker K, Kock D, Wright TL (2010) The biogeochemistry and microbiology of sulfidic mine waste and bioleaching dumps and heaps, and novel Fe(II)-oxidizing bacteria. Hydrometallurgy 104:342-350

Schloss PD, Westcott SL, Ryabin T, Hall JR, Hartmann M, Hollister EB et al (2009) Introducing mothur: open-source, platformindependent, community-supported software for describing and comparing microbial communities. Appl Environ Microbiol 75:7537-7541

Schloss PD, Gevers D, Westcott SL (2011) Reducing the effects of PCR amplification and sequencing artifacts on 16S rRNA-based studies. PLoS One 6:e27310

Simate GS, Ndlovu S (2014) Acid mine drainage: challenges and opportunities. J Environ Chem Eng 2:1785-1803

Singer PC, Stumm W (1970) Acid mine drainage: the rate-determining step. Science 167:1121-1123

Sorokin DY, Teske A, Robertson LA, Kuenen JG (1999) Anaerobic oxidation of thiosulphate to tetrathionate by obligately heterotrophic bacteria, belonging to the Pseudomonas stutzeri complex. FEMS Microbiol Ecol 30:113-123

Stolz JF, Basu P, Santini JM, Oremland RS (2006) Arsenic and selenium in microbial metabolism. Annu Rev Microbiol 60:107-130

Takahashi Y, Suto K, Inoue C (2010) Polysulfide reduction by Clostridium relatives isolated from sulfate-reducing enrichment cultures. J Biosci Bioeng 109:372-380

Tan GL, Shu WS, Hallberg KB, Li F, Lan CY, Zhou WH, Huang LN (2008) Culturable and molecular phylogenetic diversity of microorganisms in an open-dumped, extremely acidic $\mathrm{Pb} / \mathrm{Zn}$ mine tailings. Extremophiles 12:657-664

Thermo Scientific NITON (2008) Thermo Scientific NITON ${ }^{\circledR}$ XL3t 900 Series Product specifications. http://www.thermo.com/niton (last accessed 3 Nov 2014)

Toughzaoui S, El Amari K, Benkaddour A, Hibti M, Essarraj S (2015) Hydrogeochemical and isotopic studies of the Kettara mine watershed, Morocco. Mine Water Environ 34:308-319

Turner AW (1954) Bacterial oxidation of arsenite. I. Description of bacteria isolated from arsenical cattle-dipping fluids. Aust J Biol Sci 7:452-476

Ventura BA, González F, Ballester A, Blázquez ML, Muñoz JA (2015) Bioreduction of iron compounds by Aeromonas hydrophila. Int Biodeterior Biodegrad 103:69-76

Vera M, Schippers A, Sand W (2013) Progress in bioleaching: fundamentals and mechanisms of bacterial metal sulfide oxidation. Part A. Appl Microbiol Biotechnol 97:7529-7541

Vikromvarasiri N, Boonyawanich S, Pisutpaisal N (2015) Optimizing sulfur oxidizing performance of Paracoccus pantotrophus isolated from leather industry wastewater. Energy Proc 79:629-633

Wang GW, Chen TH, Yue ZB, Zhou YF, Wang J (2014a) Isolation and characterization of Pseudomonas stutzeri capable of reducing $\mathrm{Fe}(\mathrm{III})$ and nitrate from skarn-type copper mine tailings. Geomicrobiol J 31:509-518

Wang P, Sun G, Jia Y, Meharg AA, Zhu Y (2014b) A review on completing arsenic biogeochemical cycle: microbial volatilization of arsines in environment. J Environ Sci 26:371-381

Weber KA, Achenbach LA, Coates JD (2006) Microorganisms pumping iron: anaerobic microbial iron oxidation and reduction. Nat Rev Microbiol 4:752-764

Xiu W, Guo H, Liu Q, Liu Z, Zhang B (2015) Arsenic removal and transformation by Pseudomonas sp. strain GE-1-induced ferrihydrite: co-precipitation versus adsorption. Water Air Soil Pollut 226:1-14 
Xu XJ, Chen C, Guo HL, Wang AJ, Ren NQ, Lee DJ (2016) Characterization of a newly isolated strain Pseudomonas sp. C27 for sulfide oxidation: reaction kinetics and stoichiometry. Sci Rep 6:21032. doi:10.1038/srep21032

Yamamura S, Amachi S (2014) Microbiology of inorganic arsenic: from metabolism to bioremediation. J Biosci Bioeng 118:1-9
Zeikus JG, Wolfe RS (1972) Methanobacterium thermoautotrophicum sp. nov., an anaerobic, autotrophic, extreme thermophile. J Bacteriol 109:707-713 